\title{
Biological Effects Assessment of Antibiofouling EDCs: Gaeta Harbor (South Italy) Benthic Communities' Analysis by Biodiversity Indices and Quantitative gpx4 Expression
}

\author{
Adriano Madonna ${ }^{1}$ - Agostino Balzano ${ }^{1}$ - Dea Rabbito ${ }^{1} \cdot$ Mustapha Hasnaoui $^{2}$. \\ Abdelraouf A. Moustafa ${ }^{3}$ - Nourredine Guezgouz ${ }^{4}$ - Alessia Vittorioso ${ }^{1}$.

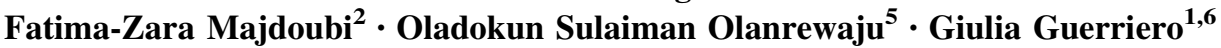

Received: 10 November 2021 / Revised: 14 November 2021/Accepted: 16 November 2021/Published online: 24 December 2021 (c) Zoological Society, Kolkata, India 2021

\begin{abstract}
The most representative organisms of the Harbor of Gaeta Gulf in South Italy were analyzed for biofouling by visual census and confirmed later by molecular approach on an artificial Conatex panel dipped $3 \mathrm{~m}$ into a eutrophic area during the Covid-19 pandemic. Mitochondrial Cytochrome $\mathrm{C}$ oxidase subunit 1(COI) gene was sequenced from 20 different marine species (flora: 2 families, 2 orders; fauna: 16 families, 11 orders) to test whether the morphology-based assignment of the most common biofouling member was supported by DNA-based species identification. Twelve months of submersion resulted in generation of sufficient data to obtain a facies climax represented mainly by the bivalve mollusk, Mytilus
\end{abstract}

Dea Rabbito

trinity0106@hotmail.it

Giulia Guerriero

giulia.guerriero@unina.it

1 Comparative Endocrinology Lab, Department of Biology, University of Naples Federico II, Via Cinthia 26, 80126 Naples, Italy

2 Environmental Engineering Team. Department of Life Sciences, Faculty of Sciences and Techniques BO. 523, University of Sultan Moulay Slimane, Beni Mellal, Morocco

3 Botany Department, Faculty of Science, Suez Canal University, Ismailia 41522, Egypt

$4 \quad$ Water and Environmental Science and Technology Laboratory, Department of Biology, Mohamed Cherif Messaadia University, Souk- Ahras, Algeria

5 Institute of Hydraulic and Water Resource Management, RWTH Aachen University, 55 Templergraben, 52056 Aachen, Germany

6 Interdepartmental Research Centre for Environment (CIRAm), University of Naples Federico II, 80134 Naples, Italy galloprovincialis. Specific diversity and variations of the biofouling biomasses were analyzed using two different anti-biofouling paints: an endocrine disrupting chemical (EDC)-containing metal biocide, and a biocide-free paint. Also, their effects on detoxification and reproductive health of M. galloprovincialis were evaluated using glutathione S-transferase enzymatic activity and RTqPCR expression of the fertility antioxidant gene glutathione peroxidase 4 (gpx4). The obtained data provide useful indications on which future investigations may be focused and may become a potential management tool for a harbor biofouling database to assist local administrations in EDCs protection of autochthonous benthic communities and their fertility using innovative antifouling paints.

Keywords Biofouling - Antifouling paints - EDCs - Gaeta Harbor $\cdot$ Benthic biodiversity index $\cdot$ COI $\cdot$ Mytilus galloprovincialis $\cdot \mathrm{GST} \cdot \mathrm{gpx} 4$

\section{Introduction}

Biofouling is the gradual accumulation of waterborne organisms such as barnacles and algae on the underwater pipes and surfaces of ship and submarine hulls contributing to their corrosion. Currently it is one of the most challenging phenomena faced by the marine technology sector, since any immersed surface in the marine environment can be affected (Ferrario et al. 2017). Examination of submerged sample materials allows identification and categorization of the submerged benthic community that lives in a particular site (Guerriero et al. 2007; Bloecher et al. 2013; Hughes and Ashton 2017). Analysis of submerged samples also allows monitoring of possible bioinvasions by alien species (Godwin 2003; Galil et al. 2019) as well as 
the state of health of the organisms that inhabit a site and the purifying capacity of filtering organisms and microorganisms present therein which could be useful for possible water remediation (Guerriero et al. 2007).

However, in general, the presence of biofouling often has negative connotations as it is mostly considered as a source of harm. In fact, it can create serious biodeterioration problems for all structures in contact with sea water, with maintenance costs estimated at billions of euros per year (Chambers et al. 2006) affecting healthcare (Fitridge et al. 2012), technological, ecological and economical (Schultz et al. 2010) sectors. Everyone is well aware of the problem of biofouling on ships' hulls and of the efforts required to manage it, as it increases water friction by making navigation less safe and reducing maneuverability, which, as is well known, results in increased fuel consumption that in the long term leads to considerable economic costs (Olanrewaju 2013).

In addition, hulls and naval structures may suffer real damage due to corrosion by microbiological communities (Sulaiman et al. 2010). In the industry, significant impacts arising from the formation of fouling are found in mariculture, membrane systems such as membrane bioreactors and reverse osmosis spiral membranes, and water cooling cycles of large industrial and electrical plants, or machinery used in the production of paper and cellulose, and also underwater instruments (Vladkova 2009). In addition to interference with the mechanical devices, biofouling also forms on the surface of living marine organisms, a phenomenon known as epibiosis, which fuels the phenomenon of diffusion of alien species in the era of climatic change (Gentilucci et al. 2021a, b).

In order to counteract the biofouling phenomenon, methods have been developed, that render the exposed surface unable for colonization but adverse effects on reproduction have been reported (Gallo and Tosti 2013; Damodaran \& Murthy 2016; Curtin et al. 2021). Companies that manufacture paints for the naval industry have the need to develop new antifouling technologies and market green-focused antifouling coatings.

Continuous monitoring is necessary to provide information about the biofouling structure. For this, the census and identification represent an important step in establishing the abundance or rarity of the biofouling species as well as to detect possibly cryptic species and even to describe new species (Di Finizio et al. 2007; Mazzeo et al. 2008; Tramice et al. 2021). The newest European Union (EU) political actions regarding maritime strategic objectives, such as the Marine Strategy Framework Directive (MSFD), and the European Strategy for Marine and Maritime Research (Bilecenoglu et al. 2013) represent a push to draw up an inventory of the alien species in the Mediterranean Sea. Furthermore, our whole project is designed to lay the foundations for future development of new technologies for environment-friendly antifouling coatings with the stringent technical inputs required by ship owners, and adhering to strict environmental directives which have respect for biodiversity and sustainability.

In an attempt to achieve these objectives, we have analyzed in this study the most representative biofouling organisms of the Harbor of Gaeta Gulf (Tyrrhenian Sea, Southern Italy) by visual census as well as through molecular approach on artificial conatex panels. Further, the variations in biofouling growth on untreated panels and panels treated with two different types of antifouling paints, one with metals (EDCs) as biocide and the other biocide-free, were evaluated through the use of biodiversity indices. In addition, the detoxifying capacity of the male gonads of a well-known bioindicator marine species the bivalve mollusk Mytilus galloprovincialis, was evaluated by means of the antioxidant glutathione S-transferase (GST) enzyme activity together with an evaluation of the reproductive health status through the expression of the antioxidant, glutathione peroxidase 4 (gpx4) gene.

\section{Material and methods}

\section{Experimental design}

This project started in March 2019. The little harbor of the Nautical School of Finance Guard in Gaeta (South Italy) was chosen as the project site. Diving and checking of the panels were made under the supervision of the first author, AM. The site is located at the farthest point of the Gulf of Gaeta (coordinates: $41^{\circ} 12^{\prime} 37.6$ “N, $13^{\circ} 35^{\prime} 20.3^{\prime}$ ” E), most exposed to currents and therefore least susceptible to anthropogenic pollution that tends to accumulate in the gulf, and which influences the outcome of the analysis. Three sets of artificial conatex experimental panels for each treatment were located in the harbor, as currently in use in the harbor of Naples also (Guerriero et al. 2007). Each panel set consists of two rows of 20 panels each (Fig. 1).

Each panel (size $10 \times 15 \times 1 \mathrm{~cm}$ ) is provided with an $8 \mathrm{~mm}$ diameter hole at each of the four corners, at a distance of approximately $2 \mathrm{~cm}$ from the edges of the panel itself. The panels were positioned one after the other by means of hydraulic clamps and spaced approximately $50 \mathrm{~cm}$ apart from each other. Each of the three panel sets has different characteristics: Type O: untreated, on which biofouling grew naturally and whose specimens were used to define the biodiversity of the harbor of Gaeta, and as a control in the laboratory analytical assays; Type A: treated with antifouling paint MX SRL, self-healing $0,75 \mathrm{~L}$ color blue; such antifouling follows a chemical and toxic approach containing copper oxide, aromatic hydrocarbons, 
Fig. 1 Artificial conatex panel with two rows of 20 panels each

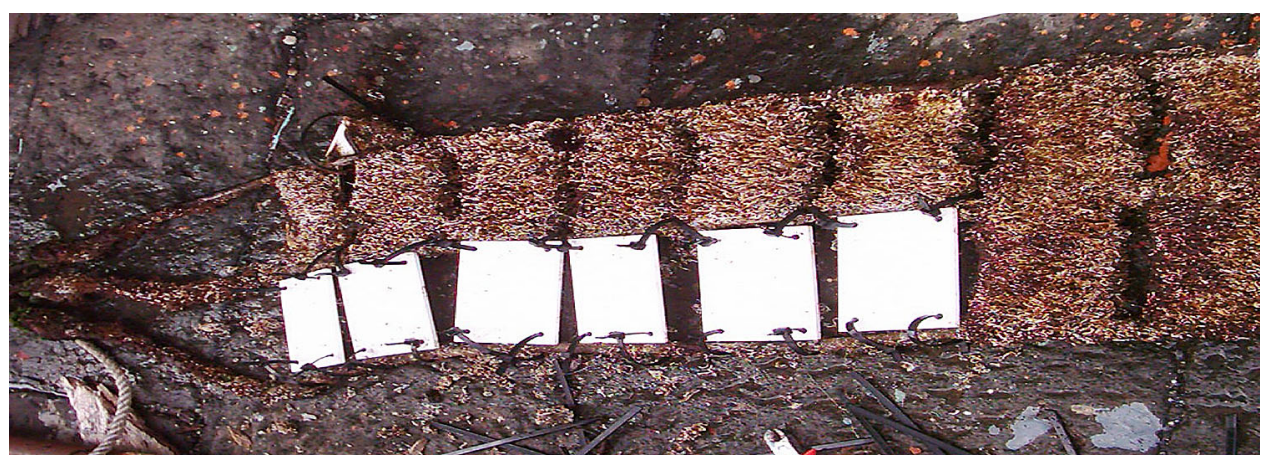

zinc oxide, rosin, and zineb as a biocide; Type B: treated with antifouling paint $\mathrm{HY}, 0,75 \mathrm{~L}$ color black; antifouling non-toxic biofoul-release without biocides, based on silicone and hydrogel.

The three panel sets were immersed vertically at a depth from 1 to $3 \mathrm{~m}$, spaced apart from each other by $15 \mathrm{~m}$ and left in the water for one year. After one year, the panels were retrieved and photographed. At the time of sampling, a series of 0 conatex panels from each treatment panel $(0$, A, B) were stored at $-20{ }^{\circ} \mathrm{C}$, the remaining series of 60 panels were placed in plastic bags to prevent loss of the organisms and fixed in formalin buffered with $19 \%$ in sea water and then, after two days, transferred to a 5-6\% formaldehyde solution and transported to the Comparative Endocrinology Laboratory of the Department of Biology (EClab), Naples University, Federico II, systematic identification by macroscopic observation and for molecular analysis as follows.

\section{Visual census}

The morphological classification was performed in accordance with the guidelines proposed in the World Porifera Database (WPD) (http://www.marinespecies.org/porifera/), the World Register of Marine Species, WoRMS (http:// www.marinespecies.org/), Algae-base (http://www.algae base.org/) and the Integrated Taxonomic Information Sys tem (http://www.itis.gov).

\section{Molecular identification}

DNA extraction and PCR amplification were performed by procedures as previously described in detail (Di Finizio et al. 2007) using the following primers: COI_UP (5'- KB TCHACAAAYCAYAARGAYATHGG -3') and COI_DW (5'-TGRTTYTTYGGWCAYCCWGARGTTTA-3'), degenerated primers that work for different organism taxa.

\section{Neighbor-Joining tree construction}

The mitochondrial cytochrome $\mathrm{C}$ oxygenase subunit I (COI) sequences, for each species, were included in the Clustal Omega program (https://www.ebi.ac.uk/Tools/msa/ clustalo/), which generates multiple alignments of nucleo tide sequences. The alignment is downloaded and con verted using the Mega6 software for implementation of the Neighbor-Joining tree.

\section{Biodiversity index}

Analysis of the biodiversity index was used to assess the quantitative distribution and relative abundance of the species. Species richness was expressed by considering the number of species (D), and species diversity, but homogeneity was determined using the Shannon-Wiener diversity index (H') and the Evenness index (J') (Pielou, 1966; Mandaville 2002). The presence of Porifera, Cnidaria and Bryozoa was reported in units of square meters $(0.5$ to 3 $\mathrm{mq}$ ), and the colonies counted as single individuals (see Table 1, relative abundance) following Loya (1972). These parameters were calculated by pooling data from the sample replicates. The percentage contribution of each taxa was calculated following Gerovasileiou \& Voultsiadou (2014). The Margalef index or Specific Wealth index was used for comparing different sites subject to different conditions following the estimation of Kocataş (1992).

\section{Enzymatic assay of the antioxidant Glutathione S-Transferase (GST)}

In order to estimate the activity of GST according to Habig et al. (1974), $250 \mathrm{mg}$ of tissue obtained from each panel and organized as pool was homogenized under liquid nitrogen with mortar and pestle. The sample followed the preparation of Guerriero et al. (2018d). GST activity was expressed as micromoles per minute per gram of tissue. 
Table 1 Common name, morphological description and taxonomic framing of each species found on the panels, characterizing biofouling (n.d.: not detected in GenBank database)

\begin{tabular}{|c|c|c|c|}
\hline Common name & Description & Taxonomy & COI accession number \\
\hline Common barnacle & $\begin{array}{l}\text { Lateral and longitudinal groove, straight basal } \\
\text { margin, spinal width of } 1 / 5 \text { of basal margin. } \\
\text { Longitudinally striped streak. Calcareous shell } \\
\text { consisting of six plaques, which combine to form } \\
\text { a small volcano-shaped structure. Brownish / } \\
\text { light lilac }\end{array}$ & $\begin{array}{l}\text { Phylum: Arthopoda } \\
\text { Class: Cirripeda } \\
\text { Order: Sessilia } \\
\text { Family: Balanidae } \\
\text { Genus: Balanus } \\
\text { Specie: Balanus perforatus (Bruguière, 1789) }\end{array}$ & KF297565 \\
\hline Striped barnacle & $\begin{array}{l}\text { Body characterized by purple / brown vertical } \\
\text { stripes. The surface of the plates has a vertical rib. } \\
\text { The operculus is diamond shaped, protected by a } \\
\text { mobile lid formed by two triangular plates }\end{array}$ & $\begin{array}{l}\text { Phylum: Arthopoda } \\
\text { Class: Cirripeda } \\
\text { Order: Sessilia } \\
\text { Family: Balanidae } \\
\text { Genus: Balanus } \\
\text { Specie: Balanus anphitrite } \\
\text { (Linneo, 1758) }\end{array}$ & JQ035527 \\
\hline Acorn barnacle & $\begin{array}{l}\text { The plates of the wall are completely fused to form } \\
\text { a steep cone. The opening is small and the base is } \\
\text { oval. The color is purple }\end{array}$ & $\begin{array}{l}\text { Phylum: Arthopoda } \\
\text { Class: Cirripeda } \\
\text { Order: Sessilia } \\
\text { Family: Pyrgomatidae } \\
\text { Genus: Megatrema } \\
\text { Specie: Megatrema anglicum (Sowerby, 1823) }\end{array}$ & FJ713101 \\
\hline Flattened barnacle & $\begin{array}{l}\text { Has a thin, smooth wall, a mandible with } 3 \text { main } \\
\text { teeth. Flattened body. Typically pink color }\end{array}$ & $\begin{array}{l}\text { Phylum: Arthopoda } \\
\text { Class: Cirripeda } \\
\text { Order: Sessilia } \\
\text { Family: Chthamalidae } \\
\text { Genus: Chthamalus } \\
\text { Specie: Chthamalus depressus (Poli, 1791) }\end{array}$ & n.d \\
\hline Large barnacle & $\begin{array}{l}\text { The presence of a short and sharp tip with spurs and } \\
\text { a slightly striated straight basal margin. It has a } \\
\text { groove on the outside, with barrel shape and } \\
\text { porous plates. Pink / bluish dye. It has larger } \\
\text { dimensions than the other barnacles }\end{array}$ & $\begin{array}{l}\text { Phylum: Arthopoda } \\
\text { Class: Cirripeda } \\
\text { Order: Sessilia } \\
\text { Family: Balanidae } \\
\text { Genus: Megabalanus } \\
\text { Specie: Megabalanus tintinnabulum } \\
\text { (Linneo, 1758) }\end{array}$ & MF314119 \\
\hline $\begin{array}{l}\text { Mediterranean } \\
\text { mussel }\end{array}$ & $\begin{array}{l}\text { The valve is externally black/ purple, with thin } \\
\text { radial and concentric growth circles towards the } \\
\text { pointed part. The two valves are held together by } \\
\text { a zipper with three or four teeth. The shape is } \\
\text { roughly quadrangular, with the edge margin } \\
\text { rounded on one side and pointed and slightly } \\
\text { curved on the other }\end{array}$ & $\begin{array}{l}\text { Phylum: Mollusca } \\
\text { Class: Bivalvia } \\
\text { Order: Mytiloida } \\
\text { Family: Mytilidae } \\
\text { Genus: Mytilus } \\
\text { Specie: Mytilus galloprovincialis (Lamark, 1819) }\end{array}$ & KF931762 \\
\hline Sea lettuce & $\begin{array}{l}\text { Has lobular lamella, irregularly expanded, fixed to } \\
\text { the substrate by rizoids. It has darker ribs and a } \\
\text { dented laminar edge. Bright green color }\end{array}$ & $\begin{array}{l}\text { Phylum: Chlorophyta } \\
\text { Class: Ulvophyceae } \\
\text { Order: Ulvales } \\
\text { Family: Ulvaceae } \\
\text { Genus Ulva } \\
\text { Specie: Ulva rigida } \\
\text { (Agardh, 1823) }\end{array}$ & n.d \\
\hline
\end{tabular}


Table 1 continued

\begin{tabular}{|c|c|c|c|}
\hline Common name & Description & Taxonomy & COI accession number \\
\hline Ectocarpales & $\begin{array}{l}\text { Filamentous alga that forms soft beards on fixed } \\
\text { substrates, up to } 20 \mathrm{~cm} \text { high. Brown color }\end{array}$ & $\begin{array}{l}\text { Phylum: Chlorophyta } \\
\text { Class: Phaeophyceae } \\
\text { Order: Ectocarpales } \\
\text { Family Ectocarpaceae } \\
\text { Genus: Ectocarpus } \\
\text { Specie: Ectocarpus siliculosus } \\
\text { (Lyngbye, 1819) }\end{array}$ & KF367762 \\
\hline Pink tube sponge & $\begin{array}{l}\text { Fleshy sponge with a solid body but soft and } \\
\text { delicate, slightly rough surface. It has a tubular } \\
\text { shape and a transparent, color-changing pink / } \\
\text { orange color }\end{array}$ & $\begin{array}{l}\text { Phylum: Porifera } \\
\text { Class: Demospongiae } \\
\text { Order: Haplosclerida } \\
\text { Family: Chalinidae } \\
\text { Genus: Haliclona } \\
\text { Specie: Haliclona mediterranea } \\
\text { (Griessinger, 1971) }\end{array}$ & n.d \\
\hline Vase sponge & $\begin{array}{l}\text { The body is long up to five inches long, fairly rigid, } \\
\text { gray in color. The sponge has an apparent hairy } \\
\text { surface }\end{array}$ & $\begin{array}{l}\text { Phylum: Porifera } \\
\text { Class: Calcarea } \\
\text { Order: Leucosolenida } \\
\text { Family: Sycettidae } \\
\text { Genus: Sycon } \\
\text { Specie: Sycon ciliatum } \\
\text { (Fabricius, 1780) }\end{array}$ & n.d \\
\hline Calcareous tube worm & $\begin{array}{l}\text { Features a body with limestone tubular segments } \\
\text { and operculo crown with small, centrally located, } \\
\text { spines }\end{array}$ & $\begin{array}{l}\text { Phylum: Anellida } \\
\text { Class: Polycheta } \\
\text { Order: Sabellida } \\
\text { Family: Serpulidae } \\
\text { Genus: Hydroides } \\
\text { Specie: Hydroides elegans } \\
\text { (Haswell, 1883) }\end{array}$ & JQ885939 \\
\hline European fan worm & $\begin{array}{l}\text { Lives inside a gray membrane tube produced by the } \\
\text { same animal, where it retreats in case of danger. } \\
\text { In the cephalic area there are filamentous gills } \\
\text { covered with eyelashes. Coloring alternates } \\
\text { between yellow-brown, uniform yellow, and } \\
\text { white }\end{array}$ & $\begin{array}{l}\text { Phylum: Anellida } \\
\text { Class: Polycheta } \\
\text { Order: Sabellida } \\
\text { Family: Sabellidae } \\
\text { Genus: Sabella } \\
\text { Specie: Sabella spallanzanii } \\
\text { (Gemlin, 1791) }\end{array}$ & KY472787 \\
\hline Brown bryozoan & $\begin{array}{l}\text { Arborescending shape with reddish brownish tufts } \\
\text { with no thorns. Presents zooids (individuals) in } \\
\text { two rows.The zoario (colony) is a corny and } \\
\text { dense bush with irregular branches. Zooide are } \\
\text { almost square, with beveled corners in the back }\end{array}$ & $\begin{array}{l}\text { Phylum: Bryozoa } \\
\text { Class: Gymnolaemata } \\
\text { Order: Cheilostomatida } \\
\text { Family: Bugulidae } \\
\text { Genus: Bugula } \\
\text { Specie: Bugula neritina } \\
\text { (Linneo, 1758) }\end{array}$ & AF061432 \\
\hline Branching bryozoan & $\begin{array}{l}\text { Limestone briozoan of sometimes red-brick red } \\
\text { color. The zoecium secreted by the single zooids } \\
\text { is porous }\end{array}$ & $\begin{array}{l}\text { Phylum: Bryozoa } \\
\text { Class: Gymnolaemata } \\
\text { Order: Cheilostomatida } \\
\text { Family: Schizoporellidae } \\
\text { Genus: Schizoporella } \\
\text { Specie: Schizoporella errata } \\
\text { (Waters, 1878) }\end{array}$ & EU797466 \\
\hline
\end{tabular}


Table 1 continued

\begin{tabular}{|c|c|c|c|}
\hline Common name & Description & Taxonomy & COI accession number \\
\hline Crisia & $\begin{array}{l}\text { Has an arborescending, bushy shape with } \\
\text { ramifications. Light yellow_-beige coloration }\end{array}$ & $\begin{array}{l}\text { Phylum: Bryozoa } \\
\text { Class: Stenolaemata } \\
\text { Order: Cyclostomatida } \\
\text { Family: Crisiidae } \\
\text { Genus: Crisia } \\
\text { Specie: Crisia ramosa } \\
\text { (Harmer, 1891) }\end{array}$ & n.d \\
\hline Pink-hearted hydroid & $\begin{array}{l}\text { The stems are tubular, with a yellow tapestry and } \\
\text { are branched to the base. The octopus color is } \\
\text { light pink and consists of a central circle of oral } \\
\text { tentacles surrounded by more exterior and large } \\
\text { tentacles }\end{array}$ & $\begin{array}{l}\text { Phylum: Cnidaria } \\
\text { Class: Hidrozoa } \\
\text { Order: Anthoathecata } \\
\text { Family: Tubulaiidae } \\
\text { Genus: Tubularia } \\
\text { Specie: Tubularia crocea } \\
\text { (Agassiz, 1862) }\end{array}$ & n.d \\
\hline Vase tunicate & $\begin{array}{l}\text { Has a body attached to the substrate by short } \\
\text { rhizomes; consisting of a thick tunic of gelatinous } \\
\text { texture and translucent appearance, whitish color. } \\
\text { It has lobed sipes. The inhaling siphon is placed } \\
\text { in an apical position, the exhaling slider is placed } \\
\text { at the bottom and in the lateral position }\end{array}$ & $\begin{array}{l}\text { Phylum: Chordata } \\
\text { Subphylum: Tunicata } \\
\text { Class: Ascidiacea } \\
\text { Order: Phlebobranchia } \\
\text { Family: Cionidae } \\
\text { Genere: Ciona } \\
\text { Specie: Ciona intestinalis } \\
\text { (Linneo, 1767) }\end{array}$ & NC_004447 \\
\hline Dirty sea squirt & $\begin{array}{l}\text { Has an oval body with conical siphon siphons } \\
\text { placed in the upper part of the body, atrial siphons } \\
\text { at the side, both with crests of darker color than } \\
\text { the gray-brown cartilage mantle }\end{array}$ & $\begin{array}{l}\text { Phylum: Chordata } \\
\text { Subphylum: Tunicata } \\
\text { Class: Ascidiacea } \\
\text { Order: Phlebobranchia } \\
\text { Family: Ascidiiae } \\
\text { Genus: Ascidiella } \\
\text { Specie: Ascidiella aspersa } \\
\text { (Müller, 1776) }\end{array}$ & KF309653 \\
\hline Star ascidian & $\begin{array}{l}\text { Has zooids growing in the shape of a star or flower, } \\
\text { enclosed in gelatinous layers arranged in regular } \\
\text { round and ovoid groups. Zooids present in a } \\
\text { colony have a single siphon and have glowing } \\
\text { colors }\end{array}$ & $\begin{array}{l}\text { Phylum: Chordata } \\
\text { Subphylum: Tunicata } \\
\text { Class: Ascidiacea } \\
\text { Order: Stolidobranchia } \\
\text { Family: Styelidae } \\
\text { Genus: Botryllus } \\
\text { Specie: Botryllus schlosseri } \\
\text { (Pallas, 1776) }\end{array}$ & AY600987 \\
\hline Sea squirt & $\begin{array}{l}\text { Colony with relatively fleshy bodies. Its thickness is } \\
\text { approximately one centimeter. The high density } \\
\text { of limestone spheres in the tissue gives a } \\
\text { consistency of skin on the surface of the colony. } \\
\text { It has a milky white / beige color }\end{array}$ & $\begin{array}{l}\text { Phylum: Chordata } \\
\text { Subphylum: Tunicata } \\
\text { Class: Ascidiacea } \\
\text { Order: Aplousobranchia } \\
\text { Family: Didemnidae } \\
\text { Genus: Didemnum } \\
\text { Specie: Didemnum fulgens } \\
\text { (Milne Edwards, 1841) }\end{array}$ & KJ725152 \\
\hline
\end{tabular}

Milne Edwards, 1841) 
Fig. 2 Cladogram of examined biofouling species
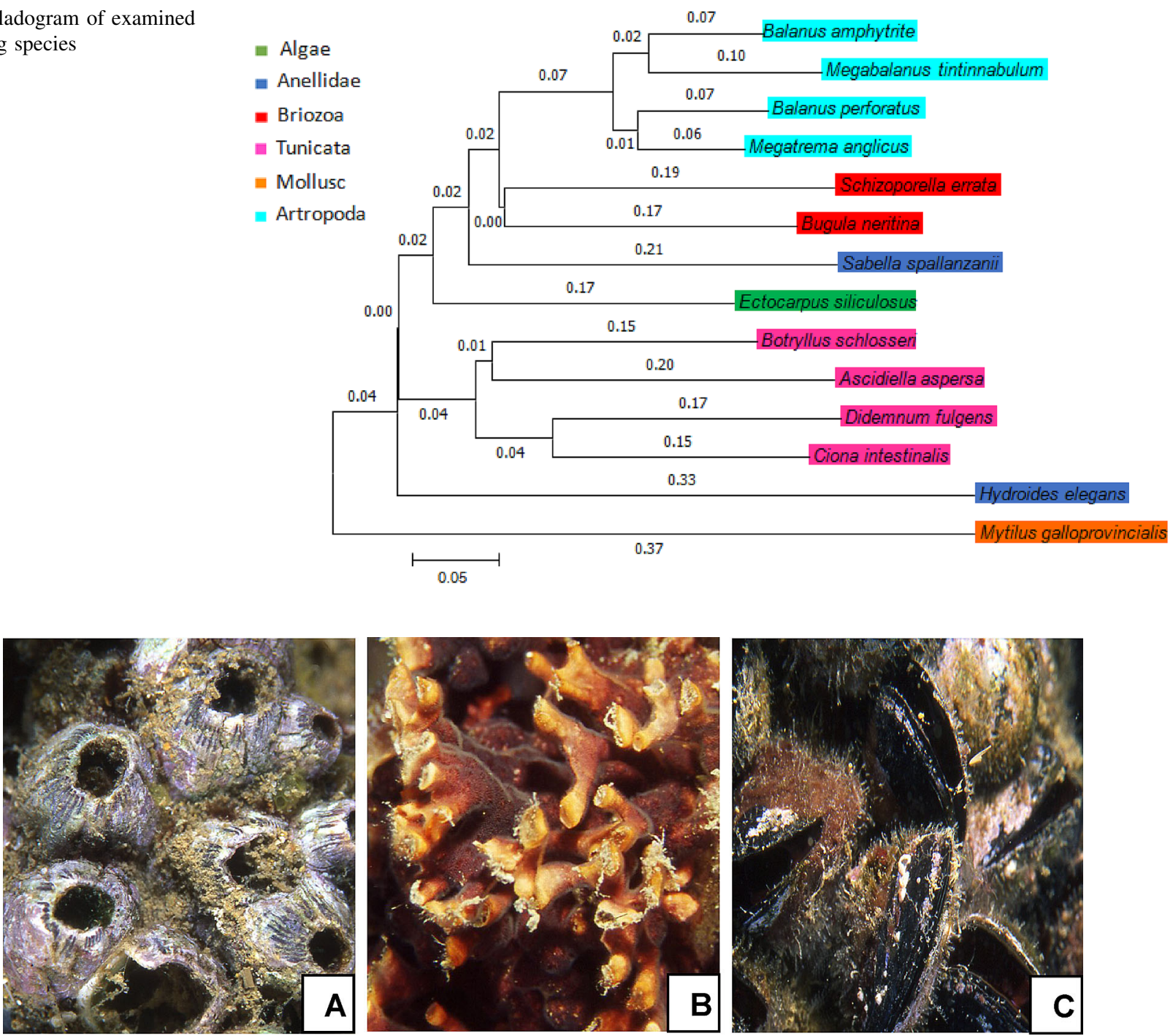

Fig. 3 The most representative biofouling species of Gaeta Harbor. A: Balanus perforates, B: Schizoporella errata, C: Mytilus galloprovincialis

\section{Quantitative evaluation of the gonadal antioxidant glutathione peroxidase 4 (gpx4)}

Gene expression of gpx4 was determined by real-time qPCR after RNA extraction and cDNA synthesis from pool of tissue $(50 \mathrm{mg}$ ) of Mytilus galloprovincialis. The speciespecific primer set was adopted by Wang et al. (2014), amplifying the House Keeping 18S rRNA (Forward: TCGGATTGGTGAGACTGGGAT; Reverse: TGCTGCCTTCTTTGGATC) and gpx4 gene (Forward: AGTCAGGAGCCTGGAACTGA; Reverse: TGCCTCCTTGTTTGTGTTTG). Real-Time PCR reactions were performed in triplicate in a One-step Plus RealTime PCR System (Applied Biosystems), using SYBR Green (Applied Biosystems) as reported by Guerriero et al. (2018d).

\section{Statistical methods}

The data were analyzed by one-way analysis of variance (ANOVA). Duncan's multiple range tests were applied to determine which means differed significantly. Data are presented as mean \pm standard deviation (SD) and $\mathrm{p}<0.05$ was considered as statistically significant.

\section{Results}

Species identification, species abundance and taxa biodiversity distribution of Gaeta Harbor biofouling

All biofouling organisms planted on the conatex panels were transported to the laboratory and examined using a morphological approach that allowed identification of the 
Table 2 Species identified on the three types of panels: $\mathrm{O}$, untreated; A, treated with copper and zinc antifouling paint; $\mathrm{B}$, treated with silicone and hydrogel antifouling paint. Average $\pm \mathrm{SD}$ of the number of specimens found on each panel

\begin{tabular}{|c|c|c|c|}
\hline Species & $\begin{array}{l}\text { Type O } \\
(\mathrm{n}=60)\end{array}$ & $\begin{array}{l}\text { Type A } \\
(\mathrm{n}=60)\end{array}$ & $\begin{array}{l}\text { Type B } \\
(\mathrm{n}=60)\end{array}$ \\
\hline Ulva rigida* & $19.3 \pm 1.6$ & $6.5 \pm 2.0$ & $12.5 \pm 2.3$ \\
\hline Ectocarpus siliculosus* & $18.5 \pm 2.3$ & $9.2 \pm 2.20$ & $15.7 \pm 1.7$ \\
\hline Haliclona mediterranea* & $11.5 \pm 1.8$ & $1.6 \pm 0.76$ & $5.23 \pm 2.41$ \\
\hline Sycon ciliatum & $27.3 \pm 1.7$ & $2.0 \pm 1.03$ & $12.4 \pm 3.1$ \\
\hline Sabella spallanzanii & $17.5 \pm 3.6$ & n.d & $12.4 \pm 2.9$ \\
\hline Hydroides elegans & $73.3 \pm 5.6$ & $18.2 \pm 2.4$ & $49.0 \pm 4.2$ \\
\hline Bugula neritina & $42.5 \pm 3.5$ & $11.6 \pm 2.5$ & $31.5 \pm 2.2$ \\
\hline Schizoporella errata* & $9.6 \pm 1.7$ & $2.3 \pm 0.77$ & $7.5 \pm 2.07$ \\
\hline Crisia ramosa & $31.2 \pm 3.3$ & $7.0 \pm 1.87$ & $19.3 \pm 3.1$ \\
\hline Tubularia crocea* & $13.3 \pm 3.7$ & $7.8 \pm 2.15$ & $11.0 \pm 2.0$ \\
\hline Ciona intestinalis & $14.6 \pm 2.6$ & n.d & $2.5 \pm 1.03$ \\
\hline Botryllus schlosseri* & $12.7 \pm 2.5$ & $4.3 \pm 1.34$ & $10.5 \pm 1.8$ \\
\hline Ascidiella aspersa & $26.5 \pm 2.9$ & $8.2 \pm 1.95$ & $19.8 \pm 1.1$ \\
\hline Didemnum fulgens* & $16.7 \pm 3.7$ & n.d & $2.2 \pm 1.15$ \\
\hline Mytilus galloprovincialis & $231.0 \pm 17.9^{* *}$ & $167.2 \pm 17.6^{* *}$ & $202.2 \pm 12.7 * *$ \\
\hline Balanus perforatus & $69.6 \pm 5.3$ & $26.2 \pm 2.8$ & $54.3 \pm 4.8$ \\
\hline Balanus amphitrite & $54.6 \pm 4.8$ & $22.7 \pm 2.6$ & $49.2 \pm 3.4$ \\
\hline Megatrema anglicum & $44.4 \pm 4.4$ & $15.2 \pm 2.3$ & $26.9 \pm 2.5$ \\
\hline Chtamalus depressus & $12.7 \pm 2.5$ & $6.3 \pm 2.21$ & $9.5 \pm 2.25$ \\
\hline Megabalanus tintinnabulum & $2.5 \pm 1.04$ & n.d & n.d \\
\hline
\end{tabular}

Abbreviation: n.d.: not detected. *: species found in colonies

$P<0.05^{* *}:$ Mytilus galloprovincialis vs. all species detected various species according to the classic taxonomic keys. Subsequently, characterization of the benthonic species present in the harbor of Gaeta was completed and described in Table 1. This table lists the common name, morphological reference and GenBank accession number of the species barcode sequences. Useful information for discrimination, scientific name and taxonomy of the flora and fauna are also included.

\section{DNA barcoding, Neighbor-Joining tree construction and biodiversity index}

The described sets of different primers successfully amplified the corresponding mitochondrial COI region fragments examined, as highlighted in the results of all sequences subjected to FASTA searches against the NCBI DNA database (see Table 1). They aligned with high similarity (99-100\%), thus confirming the preliminary morphological identification done. The data were then used for the construction of a Neighbor-Joining tree reported in Fig. 2. From the cladogram, it can be observed that most species belonging to the same class/phylum are phylogenetically close, both because they belong to the same clade, and for the reduced phylogenetic distances, expressed numerically on the arms of each clade. Figure 3 shows representative specimens of Balanus perforates, Schizoporella errata, and Mytilus galloprovincialis.

The species in question were also found on the conatex panels treated with the two different paints, although their units varies with treatment type (Table 2).

The table shows the average \pm SD of the number of specimens of every species found on each panel, Among the species found there were some that could not be counted as single individuals, as they form colonies, so we counted the clusters that they form.

Figure 4 is a graphical representation of the numeric values in Table 2 highlighting each species with different colors to highlight the phylum to which they belong.

Assessment of the population capacity of different types of panels was possible not only visually but also through the use of biodiversity indices (Table 3). For calculation of the indices, the average value of the number of specimens for each species listed in Table 2 was used.

\section{Toxicity of antifouling paint} with and without copper and zinc on the gonad of the biosentinel species Mytilus galloprovincialis

For the assay, 30 pool of gonads of Mytilus galloprovincialis having the same gonadosomatic index were selected 


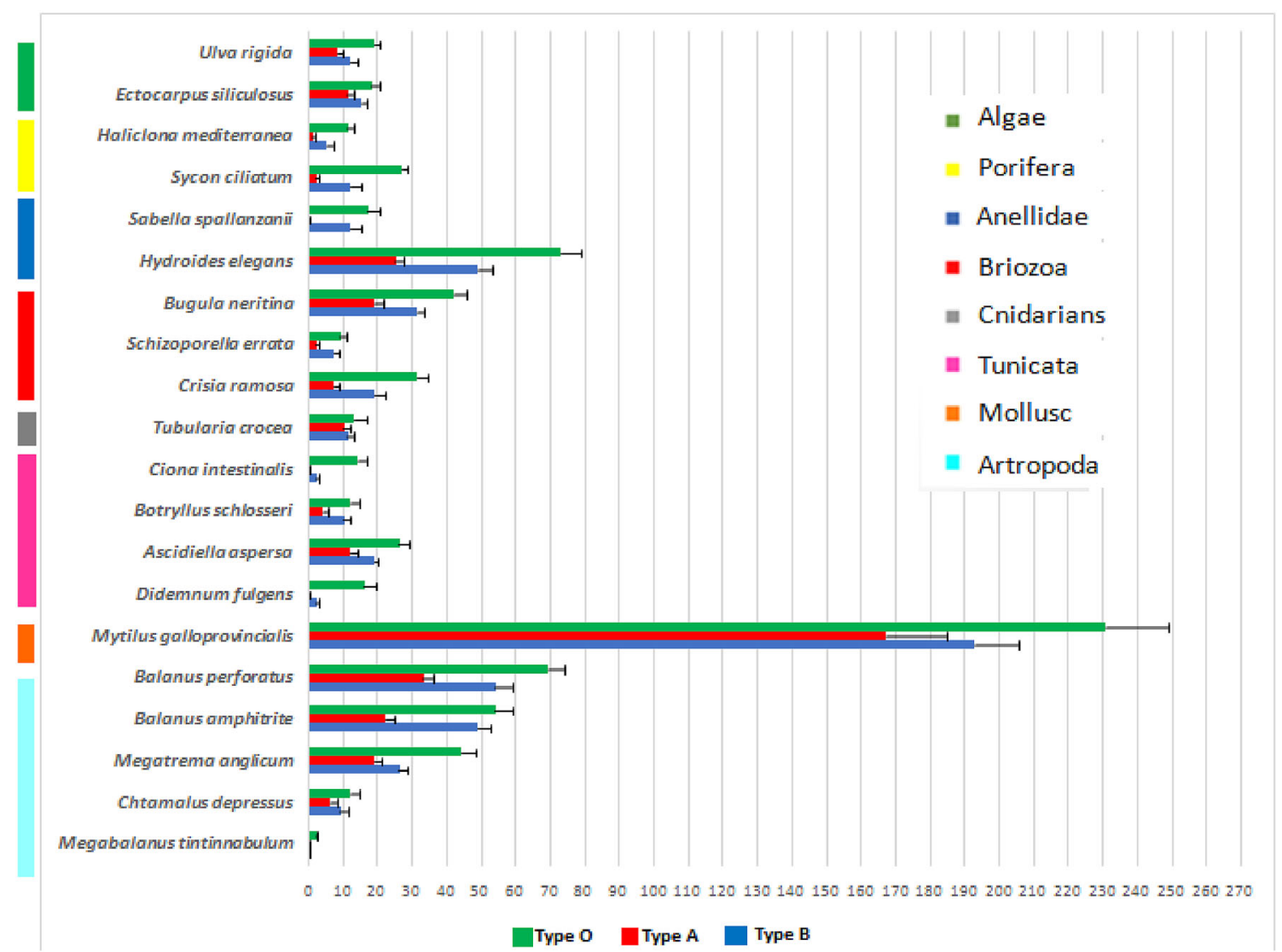

Fig. 4 Horizontal bar chart representing number of specimens for each species found on panels: O, untreated; A, treated with EDCs antifouling paint; $\mathrm{B}$, treated with silicone and hydrogel antifouling paint

Table 3 Biodiversity indexed on the panel O, untreated; A, treated with EDCs antifouling paint; B, treated with silicone and hydrogel antifouling paint

\begin{tabular}{|c|c|c|c|c|}
\hline Biodiversity index & Value range for index & Panels O & Panels A & Panels B \\
\hline Total number of species $S$ & n.1 & $20.4 \pm 3.5$ & $16.7 \pm 1.9^{*}$ & $19.2 \pm 2.0$ \\
\hline Total number of specimens $\mathrm{N}$ & n.1 & $740 \pm 25$ & $311 \pm 46^{*}$ & $546 \pm 34$ \\
\hline Shannon-Wiener index H' & $0-5$ & $2.5 \pm 0.1$ & $1.8 \pm 0.1^{*}$ & $2.3 \pm 0.2$ \\
\hline Simpson index $\Delta$ & $0-1$ & $0.87 \pm 0.03$ & $0.69 \pm 0.01 *$ & $0.83 \pm 0.07$ \\
\hline Margalef index d & n.1 & $19.8 \pm 0.5$ & $15.8 \pm 0.8^{*}$ & $18.8 \pm 0.6$ \\
\hline Pielou Evenness index J' & $0-1$ & $0.37 \pm 0.07$ & $0.32 \pm 0.09 *$ & $0.36 \pm 0.05$ \\
\hline McIntosh index Mc & $0-1$ & $0.66 \pm 0.04$ & $0.47 \pm 0.06^{*}$ & $0.61 \pm 0.07$ \\
\hline
\end{tabular}

n.1., no limit. $P<0.05$. * Panel A vs. Panel $\mathrm{O}$ and B. Values represent means $\pm \mathrm{SD}$

from the $\mathrm{O}$, A and B panels respectively. Figure 5 shows the GST activity expressed in $\mu \mathrm{M} / \mathrm{min} / \mathrm{g}$ of tissue.

The enzymatic antioxidant activity of GST is high in specimens grown on panels treated with antifouling paints of type A, treated with copper and zinc antifouling paint, with a $41 \%$ increase for mussels grown on panels, and approximately $15 \%$ for mussels grown on type B panels, compared to control samples grown on untreated type $\mathrm{O}$ panels.

As for the enzymatic assay, for the qRT PCR assay the average expression recorded in all pool tested for the three treatment groups is represented by histogram (Fig. 6), and expressed as fold change. 
Fig. 5 Glutathione

S-Transferase (GST) enzymatic activity in gonad of male specimens of Mytilus galloprovincialis grown on panel O, untreated; panel A, treated with copper and zinc antifouling paint; panel B, treated with silicone and hydrogel paint. $P<0.05$ *paint $A$ vs. untreated and paint B.

Values represent means $\pm \mathrm{SD}$ of 30 determinations from pool of each paint panel

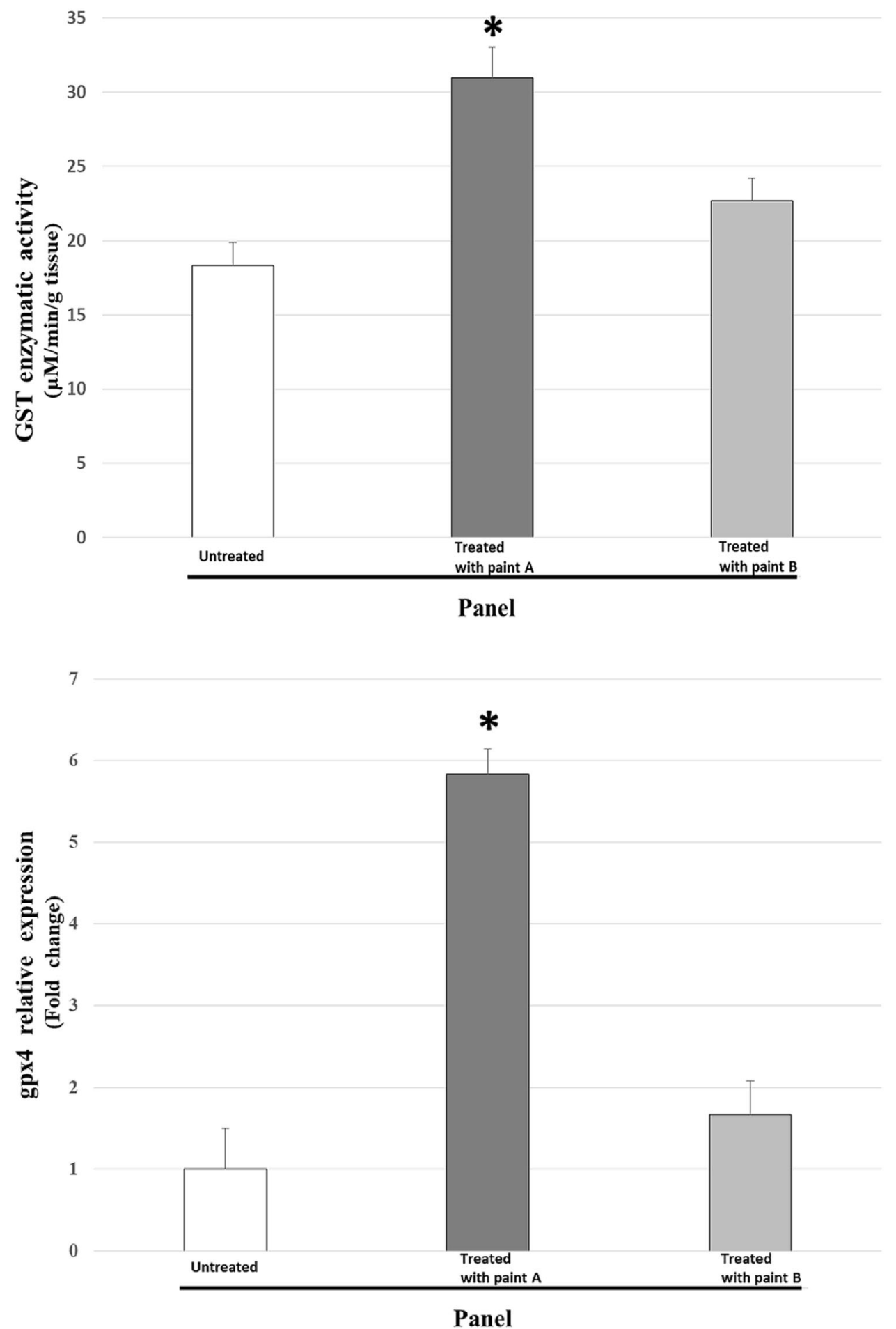

Panel
Fig. 6 Relative expression of gpx4 in the male gonad of Mytilus galloprovincialis grown on panel $\mathrm{O}$, untreated; panel $\mathrm{A}$, treated with copper and zinc antifouling paint; panel B, treated with silicone and hydrogel paint. $\mathrm{P}<0.05$ *paint $A$ vs. untreated and paint $B$. Values represent means $\pm \mathrm{SD}$ of 30 determinations from pool of each paint panel 
The gpx 4 increases in our invertebrate model on conatex panels and varies according to the type of treatment applied: it is about 6 times higher for mussels grown on type A panels, and about 2 times higher for mussels grown on type B panels compared to control samples grown on untreated panels of type $\mathrm{O}$.

\section{Discussion}

\section{Characterization of submerged benthonic communities of the harbor of Gaeta and biological effects of EDCs antifouling paint on biological indices}

Experimental observations have led to a determination of the submerged benthonic community that characterizes biofouling in Gaeta harbor. Our study allowed the identification of 20 species belonging to 8 different phyla: Arthropoda, Mollusca, Porifera, Annelida, Bryozoa, Cnidaria, Chordata, and Chlorophyta. Except for the alien species, they confirm the species already sighted in the Gulf of Naples by our research group (Guerriero et al. 2007) and in the years 2015 to date in the Gulf of Gaeta. Comparative studies will highlight the differences along the cost of the Mediterranean Sea. Beginning 2019 we established a biological index to record the average potential variation of each subphylum. The results have shown that the arthropods (barnacles) have the highest number of species, followed by the tunicates. Among the species, the presence of an alien species, $\mathrm{Me}$ gabalanus tintinnabulum, has been widespread in the Mediterranean Sea (Sciberras \& Schembri 2007).

The species with the largest number of specimens on each panel type $(\mathrm{O}$, untreated; $\mathrm{A}$, treated with copper and zinc antifouling paint; $\mathrm{B}$, treated with silicone and hydrogel antifouling paint) as shown in Fig. 4 is Mytilus galloprovincialis, and is thus the dominant species of biofouling (Vlahogianni et al. 2007). From the number and type of species specimens counted on the panels, it was possible to calculate the biodiversity indices (Table 3). According to the Shannon-Wiener index, biodiversity determined on type $\mathrm{O}$ untreated panels tends to have a stable and balanced structure, as the value assumed for that index $(2.5 \pm 0.1)$ is in the range 1.5-3 and corresponds to the optimum value (Türkmen \& Kazanci 2010). The biodiversity determined on the B-type panels treated with silicone and hydrogel is also in balance, as the index approaches this optimum $(2.3 \pm 0.2)$, albeit with a lower value than type $O$. In contrast, the value of the biodiversity index on A-type panels treated with copper and zinc (EDCs) antifouling paint $(1.8 \pm 0.1)$ was also in the optimal the range but at the lower limit, so the population is slightly diseased due to an insult caused by a form of environmental degradation as can be determined by the presence of EDCs -coated biocide paint which interferes with the biological processes of many organisms (Abel-Gawad et al. 2020).

According to the Simpson index, the type O and type B panels have largely similar values, $0.87 \pm 0.03$ and $0.83 \pm 0.07$, respectively, indicating a high diversity of population compared to the observed biodiversity on type A control panels $(0.69 \pm 0.01)$. The number of species found in a sample generally decreases under environmental stress. Therefore, it can be said that biofouling formed on type $\mathrm{O}$ panels and obtained using the index of Margalef $(d=19.8 \pm 0.5)$ has almost the same wealth of species of biofouling formed on type B panels (18.8 \pm 0.6$)$, while it is greater than that formed on type A panels (15.8 \pm 0.8$)$. Hence, the decrease in the number of species recorded in this case can be attributed to type of treatment used (Gallo and Tosti 2013). In fact, our experiments were done in water very similar to that of the reference site because during Covid-19 pandemic they resulted in reduced marine industrial activities and environmental stressors. As mentioned above, there are four species missing (Sabella spallanzanii, Ciona intestinalis, Didemnum fulgens and Megabalanus tintinnabulum), which were not found on type $\mathrm{O}$ panels, while only one missing on the type B panels (Megabalanus tintinnabulum) thus influencing the species' richness. According to the Pileou index, for all types of panels $\mathrm{O}, \mathrm{A}$ and $\mathrm{B}$ the values increase to 0.3 indicating that individuals are not equally distributed in the population. According to the McIntosh index, organisms in type $\mathrm{O}(0.66 \pm 0.04)$ and $\mathrm{B}(0.61 \pm 0.07)$ panels belonged to a more homogeneous population compared to that of type A panels $(0.47 \pm 0.06)$. From the cladogram it can also be observed that most species belonging to the same class/ phylum are phylogenetically close, because they belong to the same clade, and for the reduced phylogenetic distances expressed numerically on the arms of each clade.

\section{Biological effects of EDCs antifouling paint on the gonad of the biosentinel Mytilus galloprovincialis}

Among the biosentinel organisms detected on the panels, only two are well known for long in the scientific community, namely Ulva rigida and Mytilus galloprovincialis (Favero et al. 1996; Lionetto et al. 2003; Boubonari et al. 2008). Mytilus galloprovincialis has been studied in a large number of toxicological and investigations. Thus, it is easier to make an interpretation of the data obtained from our toxicological studies (see for review Piscopo et al. 2018a,b). Furthermore, for the real-time qPCR, a highly sensitive assay using species-specific primers, the need arises that the model tested be one which has already been widely used, and therefore the expression of their genes is known to produce 
valid and interpretable results (Bustin et al. 2005). Copper and zinc being metals, and as all endocrine disruptors, can comparatively alter oxidants, antioxidants and aromatase as well as steroids and poly(ADp-ribose)polimerases, symmetry in vertebrates as in invertebrates (Guerriero et al. 2000, Guerriero et al. 2002, Guerriero 2007, Pecoraro et al. 2017, Scalici et al. 2017, Pecoraro et al. 2018, D'Errico et al. 2018, Guerriero et al. 2018a, 2018b, 2018c, 2018d, 2018e, Piscopo et al. 2018a,b, Guezgouz et al. 2021). The enzymatic assay was performed to determine if the tissues of the analyzed organisms have been subjected to an insult due to oxidative stress from the antifouling paints.

Since the experiments were done during the Covid-19 pandemic time, it ensured limited alteration of the environment in which the specimens lived. After entering into an organism, the pollutants or xenobiotics generally undergo a chemical transformation by the action of antioxidants, a process known as biotransformation. It consists of two phases. The phase I is characterized by reductive oxidation or hydrolysis reactions, where the metabolite following the addition of an oxygen atom becomes more suitable to react with the phase II enzymes. The phase II comprises conjugation reactions involving, among others, GSTs whose physiological action consists of conjugating glutathione with xenobiotic substances, promoting detoxification and making the compounds polar so that they can easily be excreted from the body. Although several studies showed that the evolution of enzymatic activity varies between species, tissues and seasons, GST activities in Mytilus galloprovincialis, especially in the gonads, tends to increase in environmental pollution, especially from metals, compared to unmonitored control situations (Kaaya et al. 1999; Lionetto et al. 2003; Fasulo et al. 2015; Guerriero et al. 2018c). The greater detoxifying enzymatic activity can therefore be due to the presence of EDCs in type A antifoulants, while for type B, without biocides, there has been a high increase in antioxidant activity, which instead tends to be closer to type $\mathrm{O}$ control values. As with the enzymatic assay, the qRT PCR assays (Fig. 6) showed an increase in gpx4 gene expression in specimens grown on the panels treated with antifouling paints. Studies in vertebrates demonstrated the presence of gpx4 in many tissues. However, its levels and gene expressions are higher in the testis than any other tissue, suggesting a crucial role of this antioxidant enzyme in male fertility (Shi et al. 2010). Indeed, the expression of gpx4 transcript increases following treatment with $17 \beta$-estradiol (Nam et al. 2003) and in conditions of oxidative stress. It suggests that like gpx, gpx4 plays an antioxidant role in male fertility (Guthrie and Welch 2012; Guerriero et al. 2014, 2018c, 2019).

The higher level of gpx4 gene expression in mussels grown on type A panels probably indicates oxidative insult.
The present finding is consistent with the report of Wang et al. (2014) that showed increased gpx4 expression following exposure to certain contaminants. Since the specimens were sampled during the period of the year which corresponds to the stasis of reproduction and therefore does not affect the results due to the stress of the reproductive phase (Villalba 1995; Cácares-Martinez \& Figueras 1998), this increase could be attributed to the presence of biocidal substances released by type A antifouling. There is currently no report on biofouling release paints and their effects on organisms, with particular reference to the realtime assay quantitative PCR. The slight increase in gene expression in specimens grown on panels treated with type $\mathrm{B}$ antifouling may be due to the stress induced by this new antifouling technology which results in a reduced adhesion strength of the fouling organisms (Brady \& Singer 2000) with a possible increase in the gene expression of the antioxidants. Like the present observation, glutathione gene alterations in stress conditions have been detected in fish and mussels under metal exposure in nature as well as in captivity (Fasulo et al. 2015; Guerriero et al. 2018a; Abdel-Gawad et al. 2020). In addition, climate change can amplify the biological effects of metals (see review in Parisi and Guerriero 2019) and can be very dangerous in seafood feeding (Guerriero et al. 2018b).

In conclusion, this work has made it possible to define the biodiversity of the submerged benthonic community constituting the biofouling of Gaeta harbor; to identify species with a morphological approach, confirmed by the molecular method; to detect the presence of alien species; to apply indices for the study of populations; and to learn and apply enzymatic and gene expression activity assays. Taken together, the data provide useful means for monitoring the effects of EDC antifouling methods and their biological effects related to the fertility and continuity of marine, benthic species.

Acknowledgements This work was undertaken in the framework of the international consortium MUNA (MoU) and was supported by "Federico II" University, Naples, Italy. The authors thank the School of Nautical "Guardia di Finanza "of Gaeta, LT (Italy) for giving the opportunity and logistic support respectively to make a statement of biofouling structure and cataloging and detecting the health of the species using different antifouling. We also gratefully acknowledge the logistic technical support received for the collection of samples from all of the master students working on biofouling in EClab (P. Misura, V. Sequino, M. Isernia, V. Di Maio, A. Maiorano). Our sincere thanks and gratitude to Emidio Sivieri, Biomedical Engineer at The Children's Hospital of Philadelphia, Philadelphia (USA) who critically revised the English of this manuscript.

Funding "This research received no funding".

\section{Declarations}

Conflicts of interest The authors declare no conflict of interest. 


\section{References}

Abdel-Gawad, F.K., W.K.B. Khalil, S.M. Bassem, V. Kumar, C. Parisi, S. Inglese, T.A. Temraz, H.F. Nassar, and G. Guerriero. 2020. The duckweed, Lemna minor modulates heavy metalinduced oxidative stress in the Nile tilapia Oreochromis niloticus. Water 12 (11): 2983. https://doi.org/10.3390/ w12112983.

Bilecenoglu, M., J.E.F. Alfaya, E. Azzurro, R. Baldacconi, Y.Ö. Boyaci, et al. 2013. New Mediterranean Marine biodiversity records. Mediterranean Marine Science 14: 463-480.

Bloecher, N., Y. Olsen, and J. Guenther. 2013. Variability of biofouling communities on fish cage nets: A 1-year field study at a Norwegian salmon farm. Aquaculture 417: 302-309.

Boubonari, T., P. Malea, and T. Kevrekidis. 2008. The green seaweed Ulva rigida as a bioindicator of metals $(\mathrm{Zn}, \mathrm{Cu}, \mathrm{Pb}$ and $\mathrm{Cd}$ ) in a low-salinity coastal environment. Botanica Marina 51 (6): 472-484.

Brady, R.F., and I.L. Singer. 2000. Mechanical factors favoring release from fouling release coatings. Biofouling: the Journal of Bioadhesion and Biofilm Research 15 (1-3): 73-81.

Bustin, S.A., V. Benes, T. Nolan, and M.W. Pfaff. 2005. Quantitative real-time RT-PCR - a perspective. Journal of Molecular Endocrinology 34: 597-601.

Cáceres-MartÍnez, J., and A. Figueras. 1998. Long-term survey on wild and cultured mussels (Mytilus galloprovincialis Lmk) reproductive cycles in the Ria de Vigo (NW Spain). Aquaculture 162 (1-2): 141-156.

Chambers, L.D., K.R. Stokesa, F.C. Walsha, and R.J.K. Wooda. 2006. Modern approaches to marine antifouling coatings. Surface and Coatings Technology 201 (6): 3642-3652.

Curtin, A.M., M.C. Thibodeau, and H.L. Buckley. 2021. Antibiofouling efficacy of three home and personal care product preservatives: Pseudomonas aeruginosa biofilm inhibition prevention. Biofouling. https://doi.org/10.1080/08927014.2021. 1978988.

D’Errico, G., G. Vitiello, G. De Tommaso, F.K. Abdel-Gawad, M.V. Brundo, M. Ferrante, A. De Maio, S. Trocchia, A.R. Bianchi, G. Ciarcia, and G. Guerriero. 2018. Electron Spin Resonance (ESR) for the study of Reactive Oxygen Species (ROS) on the isolated frog skin (Pelophylax bergeri): a non-invasive method for environmental monitoring. Environmental Research 165: 11-18.

Damodaran, V.D., and N. Sanjeeva Murthy. 2016. Bio-inspired strategies for designing antifouling biomaterials. Biomaterials Research 20: 18.

Di Finizio, A., G. Guerriero, G.L. Russo, and G. Ciarcia. 2007. Identification of Gadoid Species (Pisces, Gadidae) by Sequencing and PCR-RFLP Analysis of Mitochondrial 12S and 16S RRNA Gene Fragments. European Food Research and Technology 225: 337-344.

Fasulo, S., G. Guerriero, S. Cappello, M. Colasanti, T. Schettino, C. Leonzio, G. Mancini, and R. Gornati. 2015. The "SYSTEMS BIOLOGY" in the study of xenobiotic effects on marine organisms for evaluation of the environmental health status: biotechnological applications for potential recovery strategies. Reviews in Environmental Science and Bio/technology 14: 339-345.

Favero, N., F. Cattalini, D. Bertaggia, and V. Albergoni. 1996. Metal accumulation in a biological indicator (Ulva rigida) from the lagoon of Venice (Italy). Archives of Environmental Contamination and Toxicology 31 (1): 9-18.

Fitridge, I., T. Dempster, J. Guenther, and R. de Nys. 2012. The impact and control of biofouling in marine aquaculture: a review. Biofouling the Journal of Bioadhesion and Biofilm Research 28 (7): 649-669.

Galil B.S., C. McKenzie, S. Bailey, M. Campbell, I. Davidson, L. Drake, C. Hewitt, A. Occhipinti-Ambrogi, and R. Piola (2019)
ICES Viewpoint background document: Evaluating and mitigating introduction of marine non-native species via vessel biofouling. ICES Ad Hoc Report 2019. 17 pp

Gallo, A., and E. Tosti. 2013. Adverse effect of antifouling compounds on the reproductive mechanisms of the ascidian Ciona intestinalis. Marine Drugs 11 (9): 3554-3568.

Gentilucci, M., A.A. Moustafa, F.K. Abdel-Gawad, S.R. Mansour, M.R. Coppola, L. Caserta, S. Inglese, G. Pambianchi, and G. Guerriero. 2021a. Advances in Egyptian mediterranean coast climate change monitoring. Water 13: 1870.

Gentilucci, M., C. Parisi, M.R. Coppola, F.-Z. Majdoubi, A. Madonna, and G. Guerriero. 2021b. Influence of Mediterranean Sea Temperature Increase on Gaeta Gulf (Tyrrhenian Sea) biodiversity. Proceedings of the Zoological Society (calcutta) 74: 91-103.

Gerovasileiou, V., E. Voultsiadou 2014 Mediterranean marine caves as biodiversity reservoirs: a preliminary overview. In Symposia on the conservation of Mediterranean marine key habitats. Portorož 1: 27-31

Godwin, S.L. 2003. Hull fouling of maritime vessels as a pathway for marine species invasions to the Hawaiian Islands. Biofouling the Journal of Bioadhesion and Biofilm Research. 19 (1): 123-131.

Guerriero, G. 2007. Seasonal steroids variations and maturity stages in the female chub, Leuciscus cephalus L. (Pisces, Cyprinidae). The Italian Journal of Zoology 74 (4): 317-324.

Guerriero, G., S. M. Bassem, F. K. Abdel-Gawad 2018a Biological responses of white sea bream (Diplodus sargus, Linnaeus 1758) and sardine (Sardine pilchardus, Walbaum 1792) exposed to heavy metal contaminated water. Emirates Journal of Food and Agriculture 688-694

Guerriero, G., S.M. Bassem, W.K.B. Khalil, T.A. Temraz, G. Ciarcia, and FKh. Abdel-Gawad. 2018b. Temperature changes and marine fish species (Epinephelus coioides and Sparus aurata): Role of oxidative stress biomarkers in toxicological food studies. Emirates Journal of Food and Agriculture 30: 205-211.

Guerriero, G., M.V. Brundo, S. Labar, A.R. Bianchi, S. Trocchia, D. Rabbito, G. Palumbo, F.K. Abdel-Gawad, and A. De Maio. 2018c. Frog (Pelophylax bergeri, Günther 1986) endocrine disruption assessment: Characterization and role of skin poly (ADP-ribose) polymerases. Environmental Science and Pollution Research 25: 18303-18313.

Guerriero, G., G. D’Errico, R. Di Giaimo, D. Rabbito, O.S. Olanrewaju, and G. Ciarcia. 2018d. Reactive oxygen species and glutathione antioxidants in the testis of the soil biosentinel Podarcis sicula (Rafinesque 1810). Environmental Science and Pollution Research 25: 18286-18296.

Guerriero, G., A. Di Finizio, and G. Ciarcia. 2002. Stress-induced changes of plasma antioxidants of aquacultured sea bass, Dicentrarchus labrax. Journal of Comparative Biochemistry and Physiology 132: 205-211.

Guerriero, G., R. Di Giaimo, O. Hentati, FKh. Abdel-Gawad, S. Trocchia, D. Rabbito, and G. Ciarcia. 2018e. Reproductive expression dynamics and comparative toxicological perspective of beta estrogen receptor gene in the male wall lizard, Podarcis sicula Rafinesque, 1810 (Chordata: Reptilia). The European Zoological Journal 85: 332-342.

Guerriero, G., C. Parisi, F.K. Abdel-Gawad, O. Hentati, and G. D'Errico. 2019. Seasonal and pharmaceutical-induced changes in selenoprotein glutathione peroxidase 4 activity in the reproductive dynamics of the soil biosentinel Podarcis sicula (Chordata: Reptilia). Molecular Reproduction and Development 86: 1378-1387.

Guerriero, G., V. Sequino, and F.P. Patti. 2007. Benthic communities analysis of the biofouling in the harbour of Naples (Italy). Biologia Marina Mediterranea 14 (2): 308-309. 
Guerriero, G., S. Trocchia, F.K. Abdel Gawad, and G. Ciarcia. 2014. Roles of reactive oxygen species in the spermatogenesis regulation. Frontiers in Endocrinology 5: 56.

Guerriero, G., C.E. Roselli, M. Paolucci, V. Botte, and G. Ciarcia. 2000. Estrogen receptors and aromatase activity in the hypothalamus of the female frog, Rana esculenta. Fluctuations throughout the reproductive cycle. Brain Research 880: 92-101.

Guezgouz, N., C. Parisi, S. Boubsil, G. Grieco, S.A. Hana, and G. Guerriero. 2021. Heavy Metals Assessment in the Medjerda River Basin (Northeastern Algeria): A Preliminary Water Analysis and Toad Skin Biopsy. Proceedings of the Zoological Society 74: 104-113. https://doi.org/10.1007/s12595-020-003426.

Guthrie, H.D., and G.R. Welch. 2012. Effects of reactive oxygen species on sperm function. Theriogenology 78 (8): 1700-1708

Habig, W.H., M.J. Pabst, and W.B. Jakoby. 1974. Glutathione-Stransferases. The first enzymatic step in mercapturic acid formation. Journal Biological Chemistry 249: 7130-7139.

Hughes, K.A., and G.V. Ashton. 2017. Breaking the ice: The introduction of biofouling organisms to Antarctica on vessel hulls. Aquatic Conservation: Marine and Freshwater Ecosystems 27: 158-164.

Kaaya, A., S. Najimi, D. Ribera, J.F. Narbonne, and A. Moukrim. 1999. Characterization of Glutathione S-Transferases (GST) Activities in Perna perna and Mytilus galloprovincialis Used as a Biomarker of Pollution in the Agadir Marine Bay (South of Morocco). Bulletin of Environment Contamination and Toxicology 62: 623-629.

Kocataş, A. 1992. Ekoloji ve Çevre Biyolojisi, Ege Üniv. Matbaası, İzmir, 564s

Lionetto, M.G., R. Caricato, M.E. Giordano, M.F. Pascariello, L. Marinosci, and T. Schettino. 2003. Integrated use of biomarkers (acetylcholinesterase and antioxidant enzymes activities) in Mytilus galloprovincialis and Mullus barbatus in an Italian coastal marine area. Marine Pollution Bulletin 46 (3): 324-330.

Loya, Y. 1972. Community structure and species diversity of hermatypic corals at Eilat, Red Sea. Marine Biology 13: $100-123$

Mazzeo, M.F., B.D. Giulio, G. Guerriero, G. Ciarcia, A. Malorni, G.L. Russo, and R.A. Siciliano. 2008. Fish Authentication by MALDI-TOF Mass Spectrometry. Journal of Agriculture and Food Chemistry 56: 11071-11076.

Mandaville, S.M. 2002. Benthic Macroinvertebrates in FreshwaterTaxa Tolerance Values, Metrics, and Protocols, Project $H-1$. Nova Scotia: Soil \& Water Conservation Society of Metro Halifax.

Nam, S.Y., I.J. Baek, B.J. Lee, C.H. In, E.Y. Jung, J.M. Yon, B. Ahn, J.K. Kang, W.J. Yu, and Y.W. Yun. 2003. Effects of $17 \beta$ estradiol and tamoxifen on the Selenoprotein phospholipid hydroperoxide glutathione peroxidase (PHGPx) mRNA expression in male reproductive organs of rats. The Journal of Reproduction and Development 49 (5): 389-396.

Olanrewaju OS (2013) Marine Technology and Sustainable Development: Green Innovations IGI Global Press, USA.313 pp

Parisi, C., and G. Guerriero. 2019. Antioxidative Defense and Fertility Rate in the Assessment of Reprotoxicity Risk Posed by Global Warming. Antioxidants 8 (12): 622.

Pecoraro, R., D. D’Angelo, S. Filice, S. Scalese, F. Capparucci, F. Marino, C. Iaria, G. Guerriero, D. Tibullo, E.M. Scalisi, A. Salvaggio, I. Nicotera, and M.V. Brundo. 2018. Toxicity evaluation of graphene oxide and titania loaded nafion membranes in zebrafish. Frontiers in Physiology. https://doi.org/10. 3389/fphys.2017.01039.

Pecoraro, R., F. Marino, A. Salvaggio, F. Capparucci, G. Di Caro, C. Ilario, A. Salvo, A. Rotondo, D. Tibullo, G. Guerriero, E.M. Scalisi, M. Zimbone, G. Impellizzeri, and M.V. Brundo. 2017. Evaluation of chronic nanosilver toxicity to adult zebrafish. Frontiers in Physiology. https://doi.org/10.3389/fphys.2017.01011.

Pielou, E.C. 1966. The Measurement of Diversity in Different Types of Biological Collections. J. Theoret. Biol. 13: 131-144.

Piscopo, M., M. Trifuoggi, R. Notariale, S. Labar, J. Troisi, A. Giarra, D. Rabbito, R. Puoti, D. de Benedictis, M.V. Brundo, A. Basile, K.V. Good, J. Ausió, and G. Guerriero. 2018a. Protamine-like proteins analysis as an emerging biotechnique for cadmium impact assessment on male mollusk Mytilus galloprovincialis (Lamarck 1819). Acta Biochimica Polonica 65: 259-267.

Piscopo, M., R. Notariale, D. Rabbito, J. Ausió, O.S. Olanrewaju, and G. Guerriero. 2018b. Mytilus galloprovincialis (Lamarck, 1819) spermatozoa: Hsp70 expression and protamine-like protein property studies. Environmental Science and Pollution Research 25: 12957-12966.

Scalici, M., L. Traversetti, F. Spani, V. Malafoglia, M. Colamartino, T. Persichini, S. Cappello, G. Mancini, G. Guerriero, and M. Colasanti. 2017. Shell fluctuating asymmetry in the sea-dwelling benthic bivalve Mytilus galloprovincialis (Lamarck, 1819) as morphological markers to detect environmental chemical contamination. Ecotoxicology 26: 396-404.

Schultz, M.P., J.A. Bendick, E.R. Holm, and W.M. Hertel. 2010. Economic impact of biofouling on a naval surface ship. Biofouling: the Journal of Bioadhesion and Biofilm Research 27 (1): 87-98.

Sciberras, M., and P.J. Schembri. 2007. A critical review of records of alien marine species from the Maltese Islands and surrounding waters (Central Mediterranean). Mediterranean Marine Science. 8 (1): 41-66.

Shi, Y., R. Buffenstein, D.A. Pulliam, and H. Van Remmen. 2010. Comparative studies of oxidative stress and mitochondrial function in aging. Integrative and Comparative Biology 50: 869-879.

Sulaiman, O.O., A.B. Saman Abd Kader, W.B. Saharuddin, W.B. Wan Nik, and K.B. Samo. 2010. Safety and environmental risk and reliability modeling process for sustainable inland water transportation system. Journal of Marine Environmental Engineering 2: 145-173.

Türkmen, G., and N. Kazanci. 2010. Applications of Various Diversity Indices to Benthic Macroinvertebrate Assemblages In Streams In A National Park In Turkey. Review of Hydrobiology 3 (2): 111-125.

Tramice, A., M. Trifuoggi, M.F. Ahmad, S.S. Lam, C. Iodice, G. Velotto, A. Giarra, S. Inglese, A. Cupo, G. Guerriero, and G. Tommonaro. 2021. Comparative Fatty Acid Profiling of Edible Fishes in Kuala Terengganu, Malaysia. Foods 10 (10): 2456.

Villalba, A. 1995. Gametogenic cycle of cultured mussel, Mytilus galloprovincialis, in the bays of Galicia (N.W. Spain). Aquaculture 130 (2-3): 269-277.

Vladkova, T. 2009. Surface Modification Approach to Control Biofouling. Marine and Industrial Biofouling, Springer Series on Biofilms. 4 (1): 135-163.

Vlahogianni, T., M. Dassenakis, M.J. Scoullos, and A. Valavanidis. 2007. Integrated use of biomarkers (superoxide dismutase, catalase and lipid peroxidation) in mussels Mytilus galloprovincialis for assessing heavy metals' pollution in coastal areas from the Saronikos Gulf of Greece. Marine Pollution Bulletin 54 (9): 1361-1271.

Wang, Q., X. Ning, Q. Zhang, F. Liu, H. Wu, Y. Zhang, and J. Zhao. 2014. Molecular characterization of two glutathione peroxidase genes in Mytilus galloprovincialis and their transcriptional responses to sub-chronic arsenate and cadmium exposure. Invertebrate Survival Journal 11: 149-162.

Publisher's Note Springer Nature remains neutral with regard to jurisdictional claims in published maps and institutional affiliations. 